\title{
Isolation and purification of anticoagulant enzymes from plant latex
}

\author{
Aeraaf Amal Khuraishi \\ Vijaya College, R.V. Road, Basavanagudi, Bengaluru-560004, India \\ M. Jayalakshmi \\ Vijaya College, R.V. Road, Basavanagudi, Bengaluru-560004, India \\ A. P. Harini \\ Vijaya College, R.V. Road, Basavanagudi, Bengaluru-560004, India \\ Achielle Sherlin Kunder \\ Vijaya College, R.V. Road, Basavanagudi, Bengaluru-560004, India \\ M. Mahesh \\ Azyme Biosciences Pvt Ltd, $9^{\text {th }}$ block Jayanagar, Bengaluru-560069, India \\ *Corresponding author. E-mail: mahesh@azymebio.com
}

\begin{abstract}
The plant latex is a complex mixture of organic, inorganic and hydrolytic enzymes such as proteases which acts as anticoagulant and finds its uses in surgeries, heart diseases and blood clot treatment. In the present study, latex was collected from Euphorbia milii, Jatropha malacophylla, Thevetia peruviana, Euphorbia pulcherimma and Artocarpus altilis to evaluate the best source of anticoagulant enzyme though four other plants were originally screened as well but failed to show the enzyme. Among the five, $A$. altilis and $J$. malacophylla showed the highest anticoagulant activity by milk clotting, blood clotting and APTT assay. The samples were subjected to three-step purification, i.e., salt precipitation, dialysis, ion exchange and gel filtration. The fold purification of $A$. altilis was found to be 5.37 and 2.31 for $\mathrm{J}$. malacophylla respectively after the gel filtration. The percentage of yield of $A$. altilis was found to be $63.23 \%$ and $26.4 \%$ for J. malacophylla. Molecular weight of $J$. malacophylla sample and $A$. altilis was found to be $\sim 80 \mathrm{kDa}$ and $\sim 105 \mathrm{kDa}$ respectively, determined by SDS PAGE. Both enzymes showed optimum activity at $\mathrm{pH} 7$. A. altilis showed optimum activity at $35^{\circ} \mathrm{C}$, incubation time of 40 minutes, substrate concentration of $60 \mathrm{mM}$, with $\mathrm{MgCl}_{2}$ as activator the activity increased at $600 \mu \mathrm{L}$ and with EDTA as inhibitor the activity increased at $400 \mu \mathrm{L}$. J. malacophylla showed optimum activity at $45^{\circ} \mathrm{C}$, incubation time of 10 minutes, substrate concentration of $80 \mathrm{mM}$ and stable at $35{ }^{\circ} \mathrm{C}$ which is the human body temperature. A. altilis showed optimum conditions for human administration making it therapeutically viable.
\end{abstract}

Keywords: Anticoagulant, APTT, Gel filtration, lon exchange, SDS PAGE

\section{INTRODUCTION}

Latex is an aqueous emulsion found in the vacuoles of special secretory cells called laticifers, which contain lipids, rubbers, resins, sugars, many proteins and enzymes (Fonseca et al., 2010). The latices of several plants are medicinally important and are exclusively used as a common remedy for immediate blood clotting in fresh cuts and assist in wound healing (Shivaprasad et al., 2010).

Anticoagulants are the group of drugs whose role is to prevent coagulation, unlike fibrinolytic drugs whose role is to stimulate the breakdown of a formed clot. (Yentis et al., 2004). Clinically, anticoagulants are used for a variety of conditions, but always for the same reason - to prevent aberrant clot formation, a result of the presence of a hyper-

\section{Article Info}

DOI: 10.31018/jans.v11i1.1971

Received: December 20, 2018

Revised: February 27, 2019

Accepted: March 2, 2019

\section{How to Cite}

Khuraishi, A. A. et al. (2019). Isolation and purification of anticoagulant enzymes from plant latex. Journal of Applied and Natural Science, 11(1): 217-222 coagulable state. The cause for this may be varied and the context will therefore direct the choice of drugs used. (David and Carl, 2009). Thrombin synthesis and fibrin formation occur rapidly at vascular injury sites. Regulation of coagulation is exerted at multiple levels, either by enzyme inhibition or by cofactor modulation activity. The most important regulators of coagulation are Antithrombin, protein $\mathrm{C}$ and protein $\mathrm{S}$. Along with TFPI and the fibrinolytic system, the main natural anticoagulant and antithrombotic mechanisms is constituted by these in organisms. Serine-protease inhibitor antithrombin (AT) inhibits most of the enzymes generated during activation of coagulation. AT preferentially inhibits free enzymes, whereas enzymes that are part of the intrinsic tenase or prothrombinase complexes are less accessible for inhibition (De Caterina et al., 2013). 
Plant latex is used as an effective treatment for would healing in developing countries. Carica papaya latex has been used for wound healing in mice burn. In addition, ethanolic and dichloromethane extracts of Mammea americana latex have been found to possess excellent antisecretory and gastroprotective effects in all gastric models. Fig tree latex has been used to treat warts in short duration therapy with no reports of any side effect. Plant latex has clot inducing and dissolving properties in human hemostasis. (Jaruwan and Sampomg, 2011). Oral anticoagulants are effective for primary and secondary prevention of venous thromboembolism, for prevention of systemic embolism in patients with tissue or mechanical prosthetic heart valve or AF, for prevention of AMI in patients with peripheral arterial disease, for prevention of stroke, recurrent infarction, or death in patients with AMI, and for prevention of myocardial infarction (MI) in men at high risk. (Jack et al., 2001).

Latices from manguruungy plant species like Calotropis procera and C.gigantean (Ascelpiadaceae), Jatropa curcus and Euphorbia ligularia (Euphorbiaceae), Argemone mexicana (Papaveraceae), Abutilon indicum (Malvaceae), Litsea glutinosa (Lauraceae), Ficus hispida (Moraceae), Chromolaena odorata (Asteraceae), Cryptolepis buchanani (Periplocaceae), and Hyptis suaveolens (Lamiaceae) are applied over contemporary cuts to prevent haemorrhage and later applied over wounds to boost healing (Ashwani et al., 1999). Based on the review, proteolytic enzyme has lot of application and commercial value for this reason finding out the novel source for the protease enzyme is always arsenal. Small attempt has been made to evaluate the best source of proteolytic activity from the latex.

\section{MATERIALS AND METHODS}

Extraction of latex from the plant source for the proteolytic activity/anticoagulant enzyme Plant material and collection of latex: The plant latex sample of $E$. pulcherimma, C. procera, $F$. bengalensis, $F$. benjamina, S.podophyllum, $T$. peruviana, E. milii, J. malacophylla and $A$. altilis was collected early in the morning by superficial incision of stem or leaves of healthy plants and allowing the milky latex to drain in clean glass vials separately, brought to the laboratory and refrigerated till the experiment started. (Raghunath et al., 2015).

Milk coagulation and blood coagulation method: A drop of latex sample was added to a thin layer of milk taken in a petri dish. The formation of clear zone by the breakage of milk protein by the latex showed the presence of anticoagulant enzymes. The selected latex samples were Euphorbia pulcherimma, Thevetia peruviana, Euphorbia milii, Jatropha malacophylla and Artocarpus altilis, which were tested with $1 \mathrm{ml}$ of blood. The blood clotting time was noted for all samples by using $50 \mu \mathrm{L}$ of whole latex in $100 \mu \mathrm{L}$ of blood to determine the anticoagulant property, while for control $50 \mu \mathrm{L}$ of phosphate buffer was used in blood. The samples were selected depending on the longest coagulation time. Finally, the samples were subjected to APTT (Activated partial thromboplastin time) Assay and the selected latex samples were subjected to protease enzyme isolation.

Enzyme assay: Proteolytic activity was determined by the enzyme assay using $0.65 \%$ casein as a substrate. The protease activity was expressed as amount of enzyme required to produce peptide equivalent to $\mu \mathrm{g}$ of tyrosine/min/mg protein at $37^{\circ} \mathrm{C}$ and protein content was determined according to Lowry's method using Bovine serum albumin as the standard protein (Lowry et al., 1951).

\section{Purification}

Ammonium sulphate precipitation: The crude enzyme of Artocarpus altilis and Jatropha malacophylla was precipitated by addition of $44 \%$ ammonium sulphate to $70 \%$ saturation. The enzyme was incubated overnight at $4^{\circ} \mathrm{C}$. The enzyme was then centrifuged at 6000RPM for 10 minutes and the supernatant was discarded. The pellet was dissolved in $10 \mathrm{ml}$ of $10 \mathrm{mM}$ Tris $\mathrm{HCl}$.

Dialysis: Cellulose acetate membrane with a molecular weight cut off $8 \mathrm{kDa}$ was used for the dialysis. (Mishra et al., 2017). The membrane was activated by adding $100 \mathrm{ml}$ of boiling water taken in a beaker to which $2 \%$ Sodium Bicarbonate was added and boiled for 20 minutes. The membrane was then transferred to a beaker of $100 \mathrm{ml}$ of boiling water and boiled for 20 minutes. The membrane was cooled and one end of the membrane was tied making sure there is no leakage. The precipitated sample was added of the membrane and the open end was tied. The membrane bags are suspended in a beaker containing water and incubated overnight at $4^{\circ} \mathrm{C}$. The water in the beaker was changed and stirred using magnetic stirrer for 30 minutes. The water was again changed and stirred three times.

Ion exchange: Pre-processing of column was done by washing with methanol and drying it. The chromatography column packed with DEAE (Diethyl Amino Ethyl) cellulose was washed using distilled water one to two times and sonicated for 15 minutes. The matrix was activated using activation buffer of concentration of $1 \mathrm{M}$ of $\mathrm{NaCl}$ and Tris $\mathrm{HCl}$. (Moidutty et al., 2015). The dialyzed enzyme was poured in the column and collected till the mark. The buffers of concentrations of $25 \mathrm{mM}$, $50 \mathrm{mM}, 75 \mathrm{mM}, 100 \mathrm{mM}$ and $125 \mathrm{mM}$ were added and the elusions were collected in 5 test tubes and incubated overnight at $4^{\circ} \mathrm{C}$.

Gel filtration: The elusion with highest protein activity determined by the method of Lowry et al. 
(1951) was used for Gel Filtration. SEPHADEX G75 resin was loaded in the column and left to settle. (Mishra et al.,2017). The elusion was added followed by $20 \mathrm{ml}$ phosphate buffer of $\mathrm{pH} 7.5$ of $0.1 \mathrm{M}$ concentration. 20 elusions were collected with $1 \mathrm{ml}$ per eppendorf at the rate of $1 \mathrm{ml}$ per 2 minutes. The highest protease activity was determined at 280nm using Spectrophotometer and the specific activity was calculated.

Characterization: The enzymes of $A$. altilis and $J$. malacophylla were assayed to find their stability under different parameters. This was done by subjecting the enzyme to the $\mathrm{pH}$ ranging from 410 using $0.1 \mathrm{M}$ sodium acetate buffer $(\mathrm{pH} 4,5,6)$, $0.1 \mathrm{M}$ Phosphate Buffer ( $\mathrm{pH} 7,8)$ and $0.2 \mathrm{M}$ Glycine Buffer $(\mathrm{pH} \mathrm{9,10).} \mathrm{The} \mathrm{enzymes} \mathrm{were}$ checked for maximum activity under the temperature ranges of $25^{\circ} \mathrm{C}, 35^{\circ} \mathrm{C}, 45^{\circ} \mathrm{C}, 55^{\circ}$ and $65^{\circ} \mathrm{C}$ along with incubating the enzyme for different time durations of $10-60$ minutes. By the addition concentrations $0.2-1.2 \%$ of Casein as substrate the enzyme activity was checked. The above methods were verified by Photospectrometry. (El-Hofi et al., 2014; Das et al., 2010 and El-Bendary et al., 2007).

Determination of molecular weight: Molecular weight of the protein was determined by the sodium dodecyl sulphate-polyacrylamide gel electrophoresis (SDS-PAGE) (Sunita et al., 2013). The gels ( $12 \%$ separating gel and $4 \%$ stacking gel) were loaded with a mixture of denatured $50 \mu \mathrm{l}$ enzyme and $50 \mu \mathrm{l}$ SDS loading dye. After run down, the gel was stained with Coomassie Brilliant Blue R-250 and then decolorized with a solution containing methanol and acetic acid (Yang et al., 2017).

\section{RESULTS AND DISCUSSION}

Screening for proteolytic activity: From the many plant latex samples collected, latex of 5 different plants such as Euphorbia pulcherimma, Thevatia peruviana, Euphorbia milii, Jatropha mal-

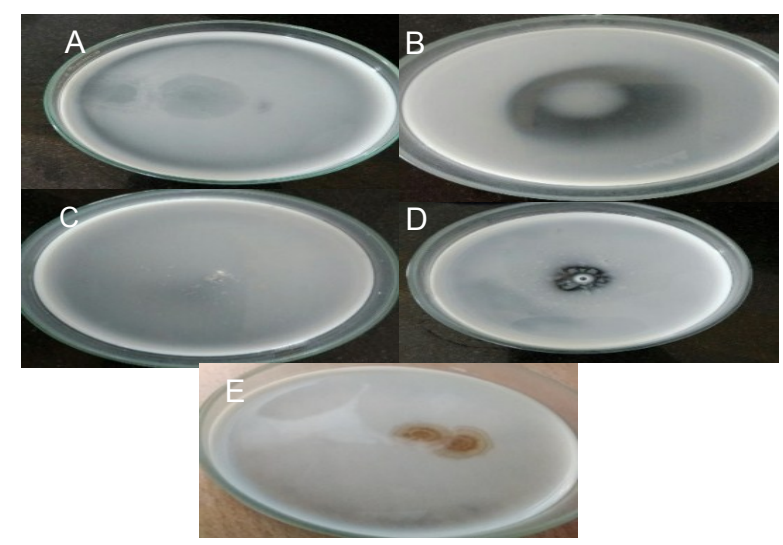

Fig. 1. Milk clotting activity seen in, A. Euphorbia pulcherimma B. Thevatia peruviana C. Euphorbia milii D. Jatropha malacophylla E. Artocarpus altilis. acophylla and Artocarpus altilis showed caseinolytic activity and milk clotting activity. All the five latex showed a clear zone formation when they were added to a thin layer of milk taken in petri dishes signifying the ability of caseinolysis(Fig. 1). Euphorbia pulcherimma, Thevatia peruviana and Euphorbia milii showed positive results while Jatropha malacophylla and Artocarpus altilis showed high proteolytic activity where blood did not coagulate (Fig. 2). The plants Euphorbia pulcherrima, Jatropha malacophylla and Artocarpus altilis are plants on which research work is rarely done. When APTT Assay was done using the plants with high proteolytic activity, Jatropha malacophylla and Artocarpus altilis did not show gel formation affirming the presence of coagulation inhibitors.

Purification: Latex of Artocarpus altilis and Jatropha malacophylla was taken for purification, which was done by four-step process of Ammonium sulphate precipitation, Dialysis, Ion Exchange and Gel filtration in order to obtain the pure enzyme with the most efficient activity. After dialysis, first elution solution of Artocarpus altilis and second elution solution of Jatropha malacophylla showed highest enzyme activity which was purified by DEAE cellulose column for SEPHADEX gel filtration. The obtained elutions were checked for enzyme activity spectrometrically. Twenty elusions were collected out of which the sixteenth elusion of Artocarpus altilis and Jatropha malacophylla showed highest protease activity. Table 1 and Table 2 summarize the results of the purification of protease from $5 \mathrm{ml}$ latex of the plant.

A. altilis shows enzyme activity of $1.72 \mathrm{mg} / \mathrm{ml}$, percentage yield of $63.23 \%$ and fold purification of 5.37 after gel filtration(Table 1), while J. malacophylla showed enzyme activity of $0.56 \mathrm{mg} / \mathrm{ml}$, percentage yield $26.41 \%$ and fold purification 2.312 (Table 2). When compared, $A$. altilis showed significant higher values than $J$. malacophylla in terms of both protease activity and purified enzyme. $A$. altilis and $J$. malacophylla showed higher percentage yield than Plumeria rubra Linn which gave 7.95\% (Chanda et al., 2011) and enzyme obtained from Bacillus spp. showed percentage yield of 7.5\% (Vengadaramana et al., 2011) also in enzyme purified from Bacillus sphaericus, the per-

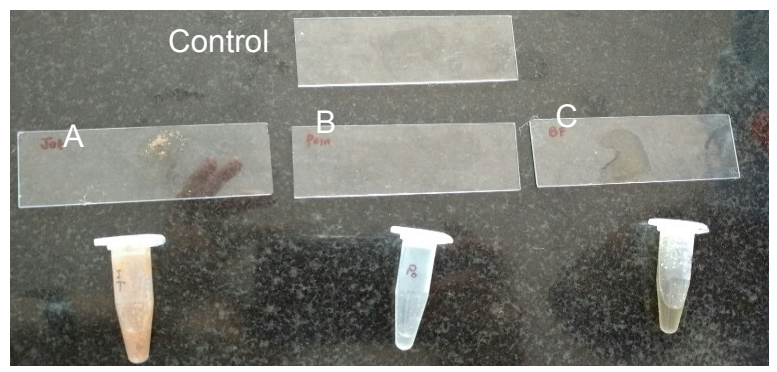

Fig. 2: APTT Assay on A. Jatropha malacophylla, B. Euphorbia pulcherrima and, C. Artocarpus altilis 
Khuraishi, A. A. et al. / J. Appl. \& Nat. Sci. 11(1): 217-222 (2019)
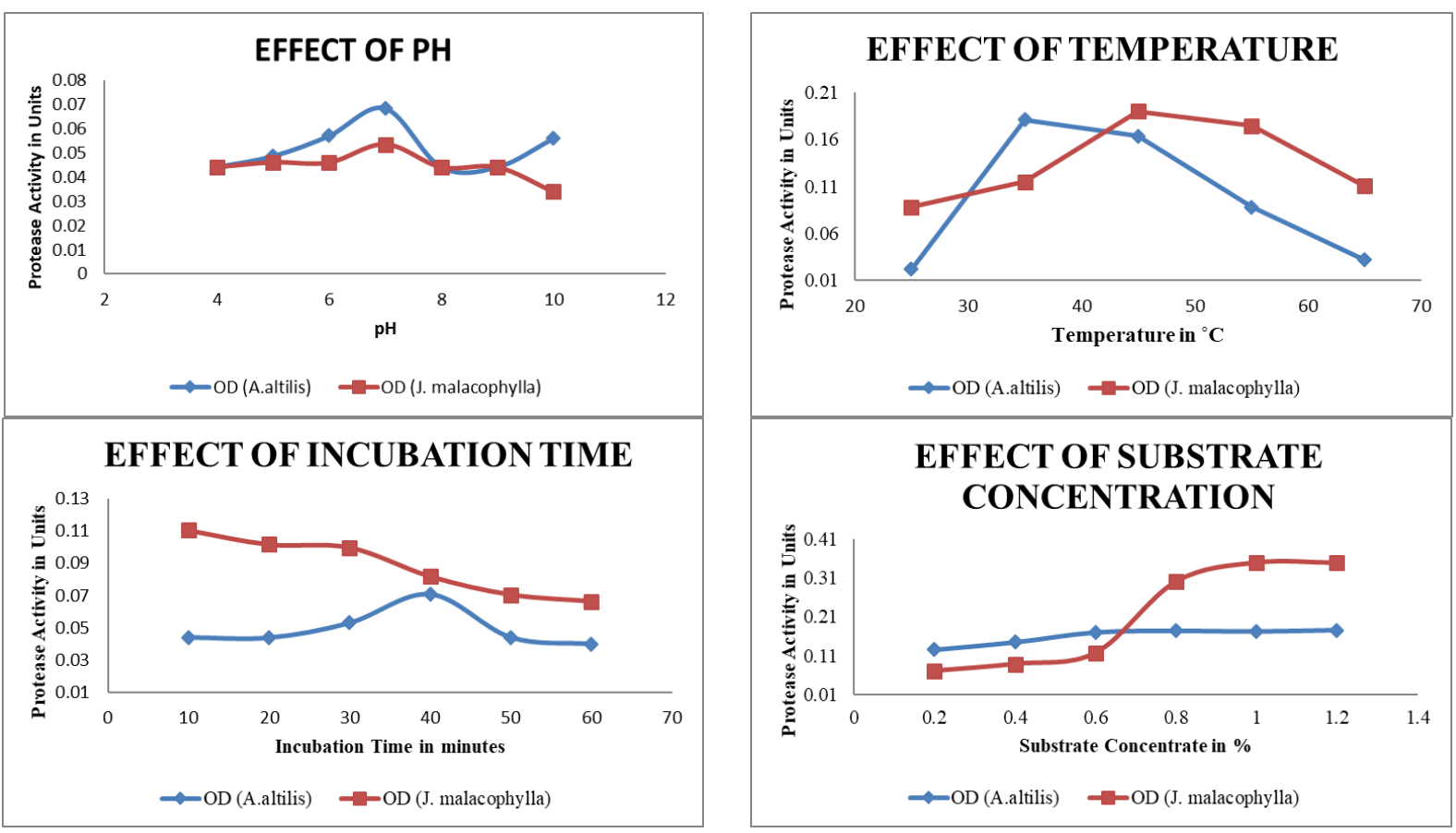

Fig. 3. Graphical representation of the characterized enzyme activity of A.altilis and M.malacophylla

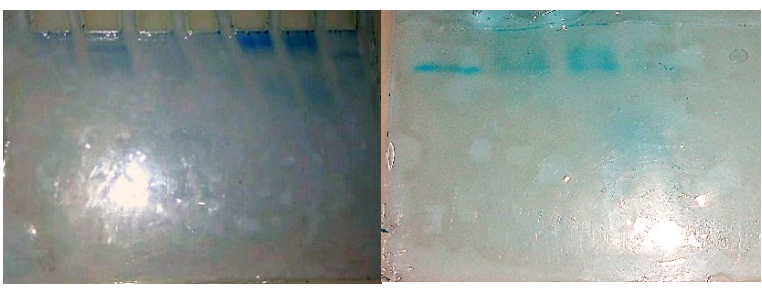

Fig. 4. SDS-Polyacrylamide Gel Electrophoresis of the Purified latex of $A$. altilis and J. malacophylla.

centage yield was found to be $25 \%$ (Balaraman et al., 2007) proving A.altilis being a better source than any of the above mentioned.

Characterization: The optimum $\mathrm{pH}$ for proteolytic activity of both the plant latex was around 7.0. The enzyme obtained from $J$. malacophylla was very stable in the range of 5 to 6 while $A$. altilis was stable in the range 4 to 5 . Above $\mathrm{pH} 7.5$, enzyme activity abruptly decreased. (Dubey et al., 2011). This signifies that the enzyme works well in the body conditions of mammals at neutral $\mathrm{pH}$ in stable state. Plumeria rubra showed similar results which is reported by Chanda et al. (2011) while protease obtained by Chickpeas was stable at $\mathrm{pH}$ 8.0 (Shamsi et al., 2016). The effect of temperature on specific protease activity was found out by varying the temperature at $25^{\circ} \mathrm{C}, 35^{\circ} \mathrm{C}, 45^{\circ} \mathrm{C}, 55^{\circ}$ $\mathrm{C}$ and $65^{\circ} \mathrm{C}$. A altilis showed optimum activity at $35^{\circ} \mathrm{C}$ and $\mathrm{J}$. malacophylla showed optimum activity at $45^{\circ} \mathrm{C}$. Normal human body temperature is $37^{\circ} \mathrm{C}$, which is close to the optimum temperature of $A$. altilis, inferring that the enzyme will show its full potential when put for clinical use. Whereas the protease of $\mathrm{J}$. malacophylla is thermally stable at $45^{\circ} \mathrm{C}$ unlike other found enzymes, which change their conformation when exposed to high temperature. Bengal gram, Lentil and Groundnut showed similar result, which was reported by Akhtaruzzaman et al., (2012) inferring that A.altilis can be a possible substitute considering high demand and price of these plant products but Chickpea was stable in the range $4^{\circ} \mathrm{C}$ to $37^{\circ} \mathrm{C}$ reported by Shamsi et al., (2016) which is easily not acceptable to be used in a mammalian system. The enzymatic activity was tested at different incubation time of 10minutes, 20minutes, 30minutes, 40 minutes, 50 minutes and 60 minutes. A. altilis showed maximum activity for 10 minutes of incubation and then with increase in the incubation time the activity decreased. While in J. malacophylla, there was steady activity from 10 to 30 minutes of incubation and the maximum activity was shown at 40 minutes of incubation.

Different protein substrate concentrations of $0.2 \%$, $0.4 \%, 0.6 \%, 0.8 \%, 1.0 \%$ and $1.2 \%$ were used and it was found that maximum protease activity was observed in $0.6 \%$ concentration in $A$. altilis while in J. malacophylla in was observed in $0.8 \%$. The least activity was observed in $0.8 \%$ in $A$. altilis and in J. malacophylla the least activity was in $0.2 \%$ (Racheal et al., 2015). It was seen that the enzyme obtained from Bacillus subtillis showed highest activity at $4 \%$ substrate concentration reported by Moidutty et al. (2015) showing that both J. malacophylla and $A$. altilis have a better action mode in spite of high concentration of substrate (Fig. 3).

Molecular weight determination: The apparent molecular weight of the purified protease is $\sim 80 \mathrm{kDa}$ and $\sim 105 \mathrm{kDa}$ for $A$. altilis and J. malacophylla respectively based on SDS-PAGE using 
Table 1. Protease enzyme purification yield for $A$. altilis.

\begin{tabular}{|c|c|c|c|c|c|}
\hline Sample & Protease & Activity & Specific Activity & Fold Purification & Percentage Yield \\
\hline Crude & $0.06186 \mathrm{U} / \mathrm{ml}$ & $2.72 \mathrm{mg} / \mathrm{ml}$ & $0.022 \mathrm{U} / \mathrm{mg}$ & 1 & $100 \%$ \\
\hline Salt Precipitation & $0.1281 \mathrm{U} / \mathrm{ml}$ & $2.54 \mathrm{mg} / \mathrm{ml}$ & $0.050 \mathrm{U} / \mathrm{mg}$ & 2.27 & $93.38 \%$ \\
\hline Dialysis & $0.132 \mathrm{U} / \mathrm{ml}$ & $2.34 \mathrm{mg} / \mathrm{ml}$ & $0.0564 \mathrm{U} / \mathrm{mg}$ & 2.56 & $86.02 \%$ \\
\hline Ion Exchange & $0.1962 \mathrm{U} / \mathrm{ml}$ & $2.24 \mathrm{mg} / \mathrm{ml}$ & $0.0875 \mathrm{U} / \mathrm{mg}$ & 3.977 & $82.35 \%$ \\
\hline Gel Filtration & $0.203 \mathrm{U} / \mathrm{ml}$ & $1.72 \mathrm{mg} / \mathrm{ml}$ & $0.1182 \mathrm{U} / \mathrm{mg}$ & 5.37 & $63.23 \%$ \\
\hline
\end{tabular}

Table 2. Protease enzyme purification yield for J. malacophylla.

\begin{tabular}{|c|c|c|c|c|c|}
\hline Sample & Protease & Activity & Specific Activity & Fold Purification & Percentage Yield \\
\hline Crude & $0.2474 \mathrm{U} / \mathrm{ml}$ & $2.12 \mathrm{mg} / \mathrm{ml}$ & $0.116 \mathrm{U} / \mathrm{mg}$ & 1 & $100 \%$ \\
\hline Salt Precipitation & $0.268 \mathrm{U} / \mathrm{ml}$ & $1.50 \mathrm{mg} / \mathrm{ml}$ & $0.117 \mathrm{U} / \mathrm{mg}$ & 1.0086 & $70.75 \%$ \\
\hline Dialysis & $0.244 \mathrm{U} / \mathrm{ml}$ & $1.4 \mathrm{mg} / \mathrm{ml}$ & $0.174 \mathrm{U} / \mathrm{mg}$ & 1.5 & $66.03 \%$ \\
\hline Ion Exchange & $0.251 \mathrm{U} / \mathrm{ml}$ & $1.02 \mathrm{mg} / \mathrm{ml}$ & $0.246 \mathrm{U} / \mathrm{mg}$ & 2.1206 & $60.37 \%$ \\
\hline Gel Filtration & $0.1502 \mathrm{U} / \mathrm{ml}$ & $0.56 \mathrm{mg} / \mathrm{ml}$ & $0.2682 \mathrm{U} / \mathrm{mg}$ & 2.312 & $26.41 \%$ \\
\hline
\end{tabular}

Novex Sharp Prestained Protein Marker (Fig. 4). While the molecular weight of protease enzyme obtained from Chickpeas was found to be $23 \mathrm{kDa}$ by Shamsi et al (2016). This difference in the molecular weight are expected due to the difference in the features of the plant itself and also influenced by the methods of purification used.

\section{Conclusion}

In the present study, $A$. altilis and $J$. malacophylla were purified to obtain pure protease enzyme. Among the two, $A$. altilis proved itself by showing higher activity (63.23\% percentage yield), stability (optimum temperature of $35^{\circ}$ and $\mathrm{pH}$ between 4 and 5) and effectiveness. Naturally obtained enzymes tend to be more effective even in small amounts and show eminent results. Henceforth, when brought to industry level it may prove to be significantly influential and medically noteworthy. In addition, with the characters such as stability at $\mathrm{pH} 7$ and $35^{\circ} \mathrm{C}$, it is fit for treatment in mammals as it matches the body conditions. Further exploitation of these enzymes can lead to a necessary transformation in the field of medicine.

\section{REFERENCES}

1. Fonseca KC, Morais NC, Queiroz MR, Silva MC, Gomes MS, Costa JO, Mamede CC, Torres FS, Penha-Silva N, Beletti ME, Canabrava HA, Oliveira F. (2010). Purification and biochemical characterization of Eumiliin from Euphorbia milii var. hislopii latex. Phytochemistry, 71: 708-715.

2. Shivaprasad H Ventatesha, Rajesh Rajaiah, Yariswamy Manjunath and B S Vishwanath. (2010). Procoagulant Properties of Plant Latex Protease, R.M. Kini et al. (eds.) Toxins and Hemostasis, pp.591 -603. DOI: 10.1007/978-90-481-9295-3_33

3. Yentis S, Hirsch N, Smith G. (2009). Anaesthesia and Critical Care A-Z: An Encyclopaedia of Principles and Practices, $3^{\text {rd }}$ Edition Elsevier 20014; 154, Amer- ican Society of Anesthesiologists.

4. David Beard and Dr Carl Gwinnutt. (2009). Anticoagulation - An Overview, ATOTW 143.

5. De Caterina, Raffaele, Steen Husted, Lars Wallentin, Felicita Andreotti, Harald Arnesen, Fedor Bachmann, Colin Baigent, Kurt Huber, Jørgen Jespersen, Steen Dalby Kristensen, Gregory Y. H. Lip, João Morais, Lars Hvilsted Rasmussen, Agneta Siegbahn, Freek W. A. Verheugt, Jeffrey I. Weitz. (2013). General mechanisms of coagulation and targets of anticoagulants (Section I), Thrombosis and Haemostasis 109.4/2013, Ontario, Canada. doi:10.1160/TH12-100772

6. Jaruwan Siritapetawee and Sompong Thammasirirak. (2011). Purification and characterization of a heteromultimeric glycoprotein from Artocarpus heterophyllus latex with an inhibitory effect on human blood coagulation, , CTA ABP Biochimica Polonica, Vol58, No 4/2011. Khon Kaen University, Thailand.

7. Jack Hirsh, James E Dalen, David R Anderson, Leon Poller, Henry Bussey, Jack Ansell, Daniel Deykin. (2001). Oral Anticoagulants: Mechanism of Action, Clinical Effectiveness, and Optimal Therapeutic Range, Sixth CHEST; 119:8S-21S, Hamilton, Ontario, Canada.

8. Ashwani Kumar. (1999). Ayurvedic medicines: some potential plants for medicine from India. A meeting of the international forum on traditional medicines, Toyama, Japan.

9. Raghunath T. Mahajan, Yuvraj D. Adsul. (2015). Isolation, purification and characterization of serine protease from latex of Euphorbia prunifolia Jacq.3(1): 388-395, IJAR, ISSN 2320-5407

10.Lowry Oliver H., Nira J, Rosebrough, A. Lewis Farr and Rose J Randall. (1951). Protein Measurement with the Folin Phenol Reagent, The Journal of Biological Chemistry, Washington University, Missouri

11.Mishra Ashwin, Anusha P., Lakshmikantha M. R., Nagamani T. S. and Mahesh M (2017). Comparative studies on anticoagulant enzyme from plant latex samples, World Journal of Pharmaceutical Research, 6(13):375-393, Bangalore, India.

12.El-Hofi Mahmoud, Azza Ismail, Maher Nour, Osama 
Ibrahim. (2014). Isolation, purification and characterisation of transglutaminase from rosemary (Rosmarinus officinalis I.) leaves. Acta Sci. Pol., Technol. Aliment. 13(3):, 267-278, Cairo, Egypt.

13.Das Gitishree and M.P. Prasad. (2010). Isolation, purification \& mass production of protease enzyme from bacillus subtili, Int. Res. J. Microbiol, 1(2): 026031, Bangalore, India.

14.El-Bendary Magda, Maysa Moharam, Thanaa Ali. (2007). Purification and Characterization of Milk Clotting Enzyme Produced by Bacillus sphaericus, Journal of Applied Sciences Research, 3(8): 695-699, Giza, Egypt.

15.Sunita Adak and Rintu Banerjee. (2013). Biochemical Characterisation of a Newly Isolated Low Molecular Weight Lipase from Rhizopus oryzae NRRL 3562, Enzyme Engineering, 2(2)., Karagpur, India.DOI: 10.4172/2329-6674.1000118

16. Yang Shaohua, Yu Wu, Jun Yang, Rong Yan, Yinghui Bao, Kaiping Wang, Guoqing Liu, Wei Wang. (2017). Isolation and identification of an extracellular enzyme from Aspergillus niger with Deoxynivalenol biotransformation capability, Emir. J. Food Agric, 29 (10):742-750, China. doi: 10.9755/ ejfa.2017.v29.i10.1295

17. Chanda Indranil, Sanat Kumar Basu, Sadhan Kumar Dutta and Smriti Rekha Chanda Das, (2011). A Protease Isolated from the Latex of Plumeria rubra Linn (Apocynaceae) 1: Purification and Characterization, Trop J Pharm Res; 10 (6): 705-711, University of Benin, Nigeria. http://dx.doi.org/10.4314/tjpr.v10i6.2

18.Vengadaramana. A, Balakumar. S and Vasanthy Arasaratnam. (2011). Purification and comparison properties of crude enzyme with purified a-amylase from Bacillus licheniformis ATCC 6346, European Journal of Experimental Biology, 1(3):58-69, University of Jaffna, Sri Lanka.

19.Balaraman K. \& G. Prabakaran. (2007), Production \& purification of a fibrinolytic enzyme (thrombinase) from Bacillus sphaericus, Indian J Med Res 126, :459 -464, Puducherry, India.

20.Dubey R., J. Kumar, D. Agrawala, T. Char and P. Pusp. (2011). Isolation, production, purification, assay and characterization of fibrinolytic enzymes (Nattokinase, Streptokinase and Urokinase) from bacterial sources, Afr. J. Biotechnol,. 10(8):. 14081420, 21 February, 2011, Kolkata, India. DOI: 10.5897/AJB10.1268

21.Shamsi Tooba Naz, Priyankar Sen and Sadaf Fatima. (2016). Purification and Characterization of a Protease from Green Seeded Chickpea (Cicer arientum), JRD, 14:146, Vellore, India. DOI: 10.4172/2311 $-3278.1000146$

22.Akhtaruzzaman M., N.H.M. Rubel Mozumder, Ripa Jamal, Atikur Rahman and Tanjina Rahman. (2012). Isolation and characterization protease enzyme from leguminous seeds. Agric. Sci. Res. J, . 2(8), pp. 434440, , Dinajpur, Bangladesh.

23.Racheal, O. O., Ahmed, A. T. F., Ndigwe, E. V., \& Morakinyo, S. D. (2015). Extraction, purification and characterization of protease from Aspergillus Niger isolated from yam peels. International Journal of Nutrition and Food Sciences, 4, 125-131.

24.Moidutty Ashif, Balasubramanian T, Merit Tardos, Fasalu Rahiman OM. (2015). Production, Purification and Characterization of Fibrinolytic Enzyme Nattokinase from Bacillus subtilis, ljppr. Human, 4 (1): 8088 , Kerala, India 